\title{
Toxicity Effect of Ultraviolet (UV) Radiations on the Human Germ Cell and the Protective Role of Vitamin E
}

\author{
Dilek Pandir* \\ Faculty of Arts and Science, Department of Biology, Bozok University, Turkey \\ *Corresponding Author: Dilek Pandir, Faculty of Arts and Science, Department of Biology, Bozok \\ University, Turkey, E-mail: durak77@gmail.com
}

\begin{abstract}
The goal of this work was to show the effect of two doses (254 and $365 \mathrm{~nm}$ ) and times (15 and 60 min) of ultraviolet radiations (UVR) and demonstrate the preventive effect of vitamin $E$ (VE; $30 \mu M)$, on human germ cell using comet assay. Control and experimental groups were created and exposed to UVR and/or VE to test the effects of short $(254 \mathrm{~nm})$ and long wave $(365 \mathrm{~nm})$ of UVR at different time periods (15 and $60 \mathrm{~min})$. After exposure of radiations and VE, evaluations comet assay studies of the sperm cells' DNA were done using tail DNA\% and tail lengths. Tail DNA\% and tail lenghts were changed by the UVR on treated cells versus untreated group at $254 \mathrm{~nm}$ of $U V R(P<0.05)$. The $365 \mathrm{~nm}$ of UVR treatment $(15 \mathrm{~min})$ did not significant effect on DNA when compared with untreated group. These results suggested that VE have a protective effect on UVR-induced changes in DNA structure in all treatment times at $365 \mathrm{~nm}$ of UVR but same effect was not seen only for 15 min at $254 \mathrm{~nm}$ of UVR. 254 and $365 \mathrm{~nm}$ of UVR treatments for a long times cause toxicity of the human germ cells. In addition, VE may be effective to reverse radiation toxicity in human germ cell at certain doses.
\end{abstract}

Keywords: $U V$, Vitamin E, Semen, Radiation, DNA damage

\section{INTRODUCTION}

Ultraviolet radiations (UVR) is known as nonionizing radiations in the environment and health risk for human and animal. Radiation causes damage to especially sensitive the tissue and consumer products, medical procedures, nuclear weapons testing and occupations always affect these cells in nature [1-3].

$\mathrm{UV}$, the visible light and the infra-red rays are involved in the solar spectrum. The range of UVR is $200-400 \mathrm{~nm}$ that is just below the visible light spectrum. The $\mathrm{UV}$ is further classified as UVA (320-400 nm), UVB (280$320 \mathrm{~nm})$ and UVC (200-280 nm) depending upon its wavelengths and energy. These UV rays have different penetrance and are associated with varying pathogeneses in altering the body homeostasis [4].

Protein synthesis and DNA structure may altered by UVR with absorption of high-energy photons and reactive oxygen species (ROS) formed in the cell. They give diverse harm on organic molecule such as proteins, nucleic acids, and lipids [5-7]. Strong UV radiation, particularly UV-B (the most energetic part of the daylight spectrum) can given cellular damage via production of ROS [8]. UVA cause a weak effect owing to its lower energies and therefore its effect on DNA limited. However, some studies' results show that UVA have a important agent of DNA damage and it leads to the formation of skin cancer [9].

The UVR also incurs oxidative load and the antioxidant defense system's activity decline in the body. The various skin carcinomas such as including melanoma and single cell carcinoma may be formed by UVR. Oxidative stress may occur in imbalance between pro-oxidants (intrinsic or extrinsic) and antioxidants [4].

Vitamin E (VE) are recognized as antioxidants which prevent cellular molecules from reactive oxygen species inducing damages on different biological processes for example wound healing, collagen synthesis, immune stimulation, prevention of anemia, gene expression, and enzymatic activity regulator [10]. VE is a major chain breaking lipid soluble antioxidant. It is scavenger of free radicals in the cell membranes. The addition of $\mathrm{VE}$ to the diet at appropriate concentrations reduces thiobar bituric acid reactive substances concentration [11] and the percentage of cell abnormalities [12]. 
The alkaline comet assay is a very simplified and fast procedure and performed genotoxicity effect of DNA in vivo and in vitro conditions. The effect usually seems as single stranded and/or double stranded breaks in genetic material. It is also used to determine the availability of different types of DNA disorders [13]. Viable cells transferred into normalmelting-point agarose, detergents and alkaline salts were used the cell membrane and placed horizontal electrophoresis tank. Damaged DNA of cell run to anode of electrophoresis with single and/or double strand breaks under alkaline conditions, cells transform into head and tail of comet $[14,15]$. If DNA single or double-strand breaks are not repaired, mutated cells, micronuclei, cell anomaly, and mutations can be formed in the cell [16].

There have been no attempts to study the effect of the UVR on human germ cells. Thus, aim of this study was to examine the potential damage of UVR and demonstrate the preventive effect of VE on human sperm cells with comet assay method in vitro conditions. From this point, this work was conducted to show the possible DNA damaging effects of radiation exposure at different doses and times in this cells with VE.

\section{Material AND Methods}

\subsection{Samples}

Semen was obtained from six 30-year-old healthy male according to WHO criteria [17] (sperm number: $64 \times 10^{6} \mathrm{ml}$; motility: $72 \%$; sperm morphology: abnormal forms: $25 \%$ ). DL$\alpha$ - tocopherol (VE) and all other chemicals were supplied by Merck (Germany).

\subsection{UV Radiation Treatments}

Obtained semen from six healthy human male were kept in petri dish at standard conditions (relative humidity and temperature $36^{\circ} \mathrm{C}$ ) and were separated into six groups: control, vitamin E, 15 min treatment group, $15 \mathrm{~min}+\mathrm{VE}$ treatment group, $60 \mathrm{~min}$ treatment group, 60 min + VE treatment group and then exposed to UVR to test the effects of short $(254 \mathrm{~nm})$ and long wave $(365 \mathrm{~nm})$ of UVR at different time periods (15 and $60 \mathrm{~min}$ ). $254 \mathrm{~nm}$ and $365 \mathrm{~nm}$ waves (Camag UV Lamps, 254/365 nm) were chosen according to Guven et al [18]. For each radiation source, all treatments were replicated six times.

\subsection{Comet Assay}

Control and treatment samples were transferred into RPMI 1640 and centrifuged for 5 min after the incubation, and supernatant was obtained and PBS was added. $75 \mu \mathrm{L}$ of low melting point agarose $(0.65 \%)$ was added in treated cells. Using precoated slides with normal melting point agarose $(0.65 \%)$ were quickly layered with cell suspension and closed coverslip and then they were placed at $+4^{\circ} \mathrm{C}$ for $30 \mathrm{~min}$. Cold lysing solution was prepared with $2.5 \mathrm{M} \mathrm{NaCl}$, $100 \mathrm{mM}$ EDTA, $10 \mathrm{mM}$ Tris and $1 \%$ Triton X100 and $0.05 \mathrm{mg} / \mathrm{ml}$ proteinase $\mathrm{K}$. After solidification, slides were immersed in lysing solution at $4{ }^{\circ} \mathrm{C}$ for $1 \mathrm{~h}$ and then the slides were placed on a horizontal gel electrophoresis platform covered with electrophoresis buffer (300 mM NaOH, $1 \mathrm{mM}$ EDTA $\mathrm{pH}: 13$ ) for 20 min to allow the unwinding of the nuclear DNA [19], followed by electrophoresis at $25 \mathrm{~V}$ for 20 min in the same alkaline buffer at $4^{\circ} \mathrm{C}$. The slides were then washed neutralizing buffer $(0.4$ $\mathrm{M}$ Tris-HCl buffer, $\mathrm{pH}$ 7.5). They were stained ethidium bromide $(2 \mu \mathrm{g} / \mathrm{ml})$ by spreading $100 \mu \mathrm{l}$ staining solution and covered with a cover slip and allowed to dry.

\subsection{Assesment of Sperm DNA Damage By Image Analysis}

BS 200 ProP with software comet analysis were used for all measurement (BS 200 ProP, BAB Imaging System, Ankara, Turkey). The tail DNA\%, tail length and tail moment of DNA were calculated for six slides. All experiments were performed at least three times. If there are higher level percentage tail DNA\% and tail lenght, it could be accepted as DNA damage at higher level [20].

\subsection{Statistics}

All the experiments were evaluated for differences by one-way analysis of variance (ANOVA) with Tukey test. Significant differences were shown as standard error of the mean (SEM). Significant level used was 0.05.

\section{ReSUlts}

\subsection{Genotoxicity Assay for Radiations}

Obtained results about genotoxicity of human male germ cells were shown in Table 1 and Figures 1 and 2 . At $30 \mu \mathrm{M}$ concentrations of VE treatment had no effect on tail DNA\% and tail lengths in sperm cells as compared to nontreated cells.

Sperm treated with different doses and times of UVR exhibited more DNA damage compared to control group but this damage was not similar in all groups. Evaluated tail DNA\%, tail lenght and tail moments were significantly increased in 254 
Toxicity Effect of Ultraviolet (UV) Radiations on the Human Germ Cell and the Protective Role of Vitamin E

$\mathrm{nm}$ of UV with increasing the treatment times (15 and $60 \mathrm{~min})(\mathrm{P}<0.05)$. The \% tail DNA values ranged from $59.52 \pm 4.21$ to $99.41 \pm$ 15.18 and tail lenght values ranged from $11.82 \pm$ 3.45 to $57.12 \pm 16.45$ (Table 1, Figs 1a-f). These results indicated that VE has a statistically significant protective effect against UVRinduced changes in tail DNA\% and tail length at $15 \mathrm{~min}$ but same effect was not seen in $60 \mathrm{~min}$ at $254 \mathrm{~nm}$ of UVR. There is no statistically significant between treatment groups in DNA damage in $60 \mathrm{~min}$ and $60 \mathrm{~min}+\mathrm{VE}$ at $254 \mathrm{~nm}$ of UVR $(\mathrm{P}<0.05)$.
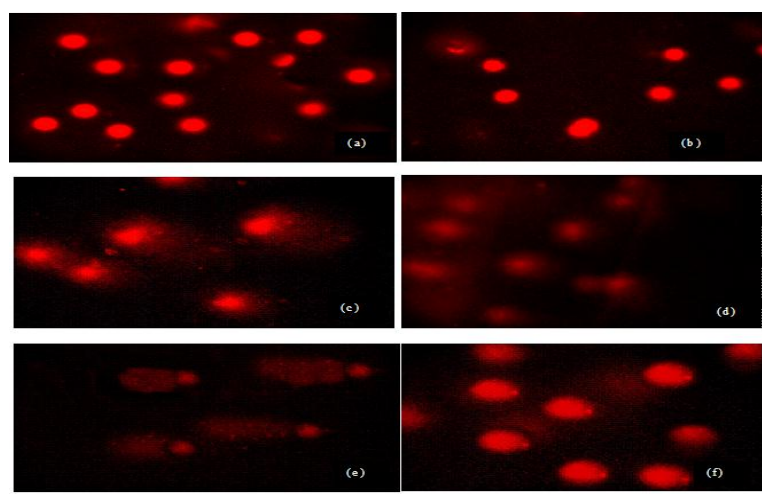

Figure 1. DNA damage in male human germ cells exposed to $254 \mathrm{~nm}$ of $U V R$ (a) control group, (b) VE treatment group (c) 15 min treatment group, (d) 15 min + VE treatment group (e) 60 min treatment group, $(f) 60$ min + VE treatment group.

Table 1. Scored DNA damage $( \pm S E)$ in cells from male human germ cells exposure UVR and/or VE with mean values of tail DNA\%, tail length and tail moment of comets by image analysis.

\begin{tabular}{|c|c|c|c|}
\hline $\begin{array}{c}\text { Different } \\
\text { exposure } \\
\text { doses of } \\
\text { radiations }\end{array}$ & $\begin{array}{c}\text { Tail DNA \% } \\
\text { Mean } \pm \text { SE }\end{array}$ & $\begin{array}{l}\text { Tail lenght } \\
\text { Mean } \pm \text { SE }\end{array}$ & $\begin{array}{l}\text { Tail moment } \\
\text { Mean } \pm \text { SE }\end{array}$ \\
\hline \multicolumn{4}{|c|}{ For 254 nm UVR } \\
\hline Control & $59.52 \pm 4.21^{\mathrm{a}}$ & $11.82 \pm 3.45^{\mathrm{a}}$ & $7.03 \pm 0.14^{\mathrm{a}}$ \\
\hline $\mathrm{VE}$ & $58.32 \pm 1.64^{\mathrm{a}}$ & $12.12 \pm 2.36^{\mathrm{a}}$ & $7.06 \pm 0.03^{\mathrm{a}}$ \\
\hline $15 \mathrm{~min}$ & $77.36 \pm 9.44^{b}$ & $33.46 \pm 5.63^{b}$ & $25.88 \pm 0.53^{b}$ \\
\hline $\begin{array}{c}150 \min + \\
V E\end{array}$ & $68.20 \pm 7.22^{c}$ & $14.78 \pm 4.25^{\mathrm{c}}$ & $10.07 \pm 0.30^{\mathrm{c}}$ \\
\hline $60 \mathrm{~min}$ & $99.41 \pm 15.18^{\mathrm{d}}$ & $57.12 \pm 16.45^{\mathrm{d}}$ & $56.78 \pm 2.49^{\mathrm{d}}$ \\
\hline $\begin{array}{c}60 \min + \\
V E\end{array}$ & $98.67 \pm 20.14^{\mathrm{d}}$ & $52.5 \pm 8.45^{\mathrm{d}}$ & $51.80 \pm 1.70^{\mathrm{d}}$ \\
\hline \multicolumn{4}{|c|}{ For 365nm UVR } \\
\hline Control & $58.84 \pm 2.65^{\mathrm{a}}$ & $11.33 \pm 1.22^{\mathrm{a}}$ & $6.66 \pm 0.03^{\mathrm{a}}$ \\
\hline $\mathrm{VE}$ & $57.74 \pm 3.23^{\mathrm{a}}$ & $11.73 \pm 1.85^{\mathrm{a}}$ & $6.77 \pm 0.05^{\mathrm{a}}$ \\
\hline $15 \mathrm{~min}$ & $59.69 \pm 16.85^{\mathrm{a}}$ & $12.45 \pm 8.45^{\mathrm{a}}$ & $7.43 \pm 1.42^{\mathrm{a}}$ \\
\hline $\begin{array}{c}15 \min \\
\mathrm{VE}\end{array}$ & $57.32 \pm 8.21^{\mathrm{a}}$ & $9.55 \pm 6.25^{\mathrm{a}}$ & $5.47 \pm 0.51^{\mathrm{a}}$ \\
\hline $60 \mathrm{~min}$ & $99.8 \pm 22.35^{b}$ & $\begin{array}{c}104.02 \pm 25.12 \\
\mathrm{~b}\end{array}$ & $\cos _{b}^{103.81 \pm 5.61}$ \\
\hline $\begin{array}{l}60 \min + \\
\mathrm{VE}\end{array}$ & $72.67 \pm 12.85^{\mathrm{c}}$ & $32 \pm 5.41^{\mathrm{c}}$ & $23.25 \pm 0.69^{c}$ \\
\hline & & & \\
\hline
\end{tabular}

ARC Journal of Nutrition and Growth
Superscript letters indicate significant differences among exposed to different times/doses of used radiations in human sperm cell. Significance at $p<$ 0.05 .
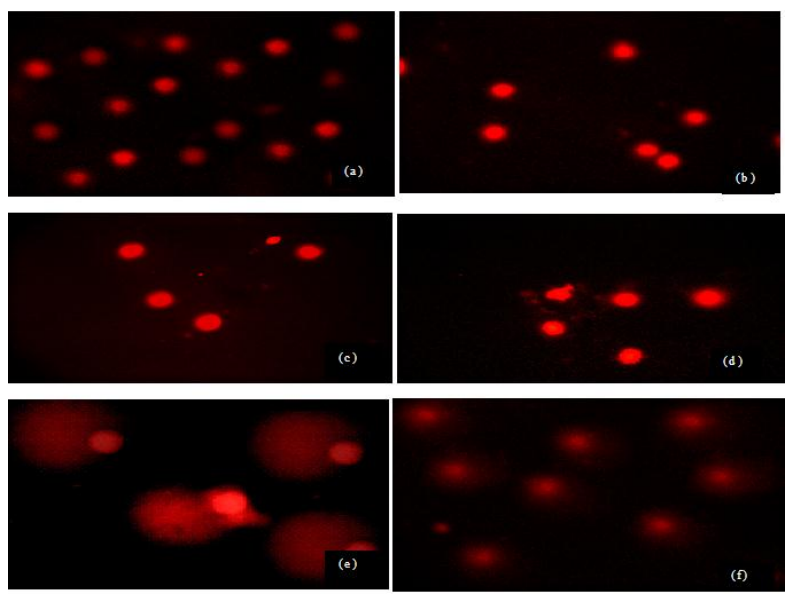

Figure 2. DNA damage in male human germ cells exposed to $365 \mathrm{~nm}$ of $U V$ radiation (a) control group, (b) VE treatment group (c) 15 min treatment group, (d) $15 \mathrm{~min}+V E$ treatment group (e) $60 \mathrm{~min}$ treatment group, $(f) 60 \mathrm{~min}+V E$ treatment group.

$365 \mathrm{~nm}$ of UVR treatment groups at $15 \mathrm{~min}, 15$ min+VE produced similar results in the percentage tail DNA\%, tail lenght and tail moments with control and VE groups. At 60 min of $365 \mathrm{~nm}$ of UVR treatment groups showed statistically significant results in tail DNA\% and tail lenght (Table 1, Figs 2a-f) (P < $0.05)$. The $\%$ tail DNA values ranged from $58.84 \pm 2.65$ to $99.8 \pm 22.35$ and tail lenght values ranged from $11.33 \pm 1.22$ to $104.02 \pm 25.12$ ( $\mathrm{P}<$ $0.05)$. VE treatment with $365 \mathrm{~nm}$ of UVR statistically significant decreased the studied parameters values for $60 \mathrm{~min}(\mathrm{P}<0.05)$.

\section{DISCUSSION}

DNA damage is closely related to human health risk. Some studies show that DNA damage statistically significant increase because of various enviromental stress factor [21-23]. Particularly, DNA damage in different cells could affect living functions and also possibly lead to degenerative diseases. Biological effects of various environmental or occupational substances on humans and animals DNA were detected by the comet assay [24-27]. In this study, after the exposure period, single strand DNA breaks was detected by micro gel electrophoresis (comet assay). Single strand DNA breaks were measured as tail DNA\%, tail length and tail moment of comet.

The effects of UVR on the pancreatic exocrine cells of male rats were examined by the electron microscope [28]. Its clearly demonstrated, particularly in the 28 days of radiation, the

Page |15 
zymogen granules decreased and vacuolated, and the rough endoplasmic reticulum was frequently shortened and dilated. In other study, the male rats of $180-200 \mathrm{~g}$ body were irradiated with artificially produced UVR for 14, 28 and 60 days. Several effects were observed in the kidney tissues cells analyzed in accordance with the dose magnitude of radiation [29]. UVR also increased the intracellular levels of hydrogen peroxide $\left(\mathrm{H}_{2} \mathrm{O}_{2}\right)$ and caused oxidative DNA damage, single strand breaks and alkali-labile sites [30]. Douki et al. [31] stated that bipyrimidine photoproducts rather than oxidative lesions are the main type of DNA damage from solar ultraviolet radiation. DNA damage was found to be positively correlated with lipid peroxide [32]. The results presented here confirm the high sensitivity of sperm, with significant increases in DNA damage after treatment of cell with doses of 15-60 min of 254 and $365 \mathrm{~nm}$ of UVR, but not following exposure to $15 \mathrm{~min}$ of $365 \mathrm{~nm}$ of UVR. In comparing the response of sperm cell after exposure to 254 and $365 \mathrm{~nm}$ of UVR, $254 \mathrm{~nm}$ of UVR showed the greatest induction of DNA damage.

The level of radiation effects on the living beings damage depends on the radiation dose received, absorbed dose and under certain exposure conditions, harmful effects of radiations may or may not occur [28]. The deformation in the cells could develop depending on the dosage and the period exposal of the radiation applied [33-35]. In this study it was shown that the increasing exposure doses and times to used radiations cause statistically significant increased disorders in sperm cell of DNA $(\mathrm{P}<0.05)$.

Several antioxidant compounds and antioxidant enzymes in biological systems prevent cells against oxidative stress [36]. Vitamin E (atocopherol) has long been recognized as being the major lipid-soluble, chain breaking antioxidant that prevents free radicals from initiating peroxidative tissue damage [37]. Several studies have also shown that $\alpha$ tocopherol inhibits free radical formation and may effectively minimize lipid peroxidation in biological systems [36]. Antioxidant addition to the diet has been shown to enhance free radical scavenging role and decrease oxidative stress [38]. Our obtained data support these statements. The human were exposed to 254 and $365 \mathrm{~nm}$ UVR for time periods of 15 and $60 \mathrm{~min}$, and the changes of DNA structure of the sperm were observed. It was seen that depending on the increasing time periods, the changes increased at $254 \mathrm{~nm}$ of UVR. Otherwise, the changes of DNA structure of the sperm at 365 $\mathrm{nm}$ of UVR did not change significantly up to the $15 \mathrm{~min}$ exposure. According to comet assay results, the tail DNA\% and tail length significantly increased with increasing exposure doses at $254 \mathrm{~nm}$ of UVR. $365 \mathrm{~nm}$ of UVR treatment groups for $60 \mathrm{~min}$ produced similar results in the percentage tail DNA\%, tail lenght and moments with $254 \mathrm{~nm}$ of UVR treatment group. VE showed ameliorative effects on UVR caused toxic effects in sperm for all examining parameters.

\section{CONClusion}

The effects of used radiations on the germ cells' DNA measured with the comet assay have not previously been described. These results show that the effect of UVR on DNA damage differs, depending on doses and times. The genetic material of germ cell of male human seems to be high sensitive to the induction damage by radiation probably due to an adaptive regulatory mechanism induced by the high level of radiations. Although $365 \mathrm{~nm}$ UVR is usually not cytotoxic in low implementation times, $254 \mathrm{~nm}$ UVR appears to enhance the levels of membran and DNA damage after increasing times. In comparing the effects of short and long-wave radiations, it was shown that $254 \mathrm{~nm}$ was more effective than $365 \mathrm{~nm}$ on this cell. In the light of these results, using cytotoxic agents might be reduced in daily life, knowing that it might promote the increasing development of defects. On the basis of these results, it is claimed that VE treatment may provide prevention against UVR caused DNA damage in the germ cell.

\section{ACKNOWLEDGEMENTS}

The author would like to thank to Fatih Oguz BEKDEMIR for helping me to prepare this study.

\section{REFERENCES}

[1] Hall E.J., Giaccia A.J., Radiobiology for the radiologist (6th ed.). Philadelphia, PA: Lippincott, Williams \& Wilkins (2006).

[2] Nias A.H.W., An introduction to radiobiology (2nd ed.). New York, NY: Wiley (1998).

[3] Sharma P., Parmar J., Sharma P., Verma P., Goyal P.K., Radiation-induced testicular injury and its amelioration by Tinospora cordifolia (an Indian medicinal plant) extract, J. Evid. Based. Complementary. Altern. Med. Article. ID 643847, 9 pages (2011).

[4] Goswami S., Haldar C., Melatonin as a possible antidote to UV radiation induced cutaneous damages and immune-suppression: An 
overview, J Photochem Photobiol 153, 281-288 (2015).

[5] Kim R.O., Rhee J.S., Won E.J., Lee K.W., Kang C.M., Lee Y.M., Lee J.S., Ultraviolet B retards growth, induces oxidative stress, and modulates DNA repair-related gene and heat shock protein gene expression in the monogonont rotifer Brachionus sp, Aquat. Toxicol. 101, 529-539 (2011).

[6] Rhee J.S., Kim B.M., Choi B.S., Lee J.S., Expression pattern analysis of DNA repairrelated and DNA damage response genes revealed by $55 \mathrm{~K}$ oligomicroarray upon UV-B irradiation in the intertidal copepod, Tigriopus japonicus, Comp. Biochem. Physiol. C. 155, 359-368 (2012).

[7] Won E.J., Lee J.S., Gamma radiation induces growth retardation impaired egg production, and oxidative stress in the marine copepod Paracyclopina nana, Aquat. Toxicol. 150, 1726 (2014).

[8] Gill S.S., Tuteja N., Reactive oxygen species and antioxidant machinery in abiotic stress tolerance in crop plants, Plant. Physiol. Biochem. 48, 909-930.

[9] Osipov A.N., Smetanina N.M., Pustovalova M.V., Arkhangelskaya E., Klokov D., The formation of DNA single-strand breaks and alkali-labile sites in human blood lymphocytes exposed to 365-nm UVA radiation, Free. Radical. Bio. Med. 73, 34-40 (2014).

[10] Mezouar D., Merzouk H., Merzouk A.S., Merzouk S.A., Belarbi B., Narce M., In vitro effects of vitamins $\mathrm{C}$ and $\mathrm{E}, \mathrm{n}-3$ and n-6 PUFA and n-9 MUFA on placental cell function and redox status in type 1 diabetic pregnant women, Placenta. 42, 114-121 (2016)

[11] Min Y., Sun T., Niu Z., Liu F., Vitamin C and vitamin $\mathrm{E}$ supplementation alleviates oxidative stress induced by dexamethasone and improves fertility of breeder roosters, Anim. Reprod. Sci. 171, 1-6 (2016).

[12] Biswas A., Mohan J., Sastry K., Effect of higher dietary vitamin Econcentrations on physical and biochemical characteristics of semen in Kadaknath cockerels, Br. Poult. Sci. 50, 733-738 (2009).

[13] Deshmukh P.S., Megha K., Banerjee B.D., Ahmed R.S., Chandna S., Abegaonkar M.P., Tripathi A.K., Detection of low level microwave radiation induced deoxyribonucleic acid damage vis-à-vis genotoxicity in brain of fischer rats, Toxicol. Int. 20, 19-24 (2013).

[14] Pereira L.L.S., Marcussi S., Sátiro L.C., Pereira C.A., Andrade L.F., Davide L.C., Santos C.D., Application of comet assay to assess the effects of white bean meal on DNA of human lymphocytes, Brazilian. J. Pharm. Sci. 48, 103108 (2012).
[15] Pavão P.R.G., Gontijo A.M.M.C., Ribeiro D.A., Salvadori D.M.F., Ausência de efeito genotóxico induzido por esteróides anabolizantes em indivíduos fisiculturistas, Rev. Bras. Educ. Fis. Esp. 21, 5-10 (2007).

[16] Hirose H., Sakuma N., Kaji N., Suhara T., Sekijima M., Nojima T., Miyakoshi J., Phosphorylation and gene expression of p53 are not affected in human cells exposed to 2.1425 $\mathrm{GHz}$ band $\mathrm{CW}$ or W-CDMA modulated radiation allocated to mobile radio base stations, Bioelectromagnetics. 27:494-504 (2006).

[17] WHO., World Health Organization laboratory manual for the examination of human semen and sperm-cervical mucus interaction, Cambridge University Press, Cambridge, UK (2000).

[18] Guven E., Pandır D., Bas H., UV radiationinduced oxidative stress and DNA damage Mediterranean flour moth Ephestia kuehniella Zeller (Lepidoptera: Pyralidae) larvae, Turk. J. Entomol. 39(1), 23-33 (2015).

[19] Ozkan D., Yuzbasioglu D., Unal F., Yilmaz S., Aksoy H., Evaluation of the cytogenetic damage induced by the organophosphorous insecticide acephate, Cytotechnology 59, 73-80 (2009).

[20] Behravan J., Mosafa F., Soudmand N., Taghiabadi E., Razavi B.M., Karimi G., Protective effects of aqueous and ethanolic extracts of Portulaca oleracea L. aerial parts on $\mathrm{H}_{2} \mathrm{O}_{2}$-induced DNA damage in lymphocytes by comet assay, Acupunct. Meridian. Stud. 4, 193197 (2011)

[21] Pandir D., Assesment of the DNA damage in human sperm and lymphocytes exposed to the carcinogen food contaminant furan with comet assay, Braz. Arch. Biol. Technol. 58(5), 773780 (2015).

[22] Pandir D., DNA Damage in human germ cell exposed to the some food additives in vitro. Cytotechnology (accepted)

[23] Lai H., Singh N.P., Acute low-intensity microwave exposure increases DNA singlestrand breaks in rat brain cells, Bioelectromagnetics 16(3), 207-210 (1995).

[24] Collins A., Dusinská M., Franklin M., Somorovská M., Petrovská H., Duthie S., Comet assay in human biomonitoring studies: Reliability, validation, and applications, Environ. Mol. Mutagen. 30, 139-146 (1997).

[25] European Standards Committee on Oxidative DNA Damage (ESCODD), Measurement of DNA oxidation in human cells by chromatographic and enzymic methods, Free. Radic. Biol. Med. 34, 1089-1099 (2003).

[26] Kumaravel T.S, Vilhar B., Faux S.P., Jha A.N., Comet Assay measurements: A perspective, Cell, Biol, Toxicol, 25, 53-64 (2009).

Page |17 
[27] Garaj-Vrhovac V., Orescanin V., Assessment of DNA sensitivity in peripheral blood leukocytes after occupational exposure to microwave radiation: The alkaline comet assay and chromatid breakage assay, Cell. Biol. Toxicol. 25, 33-43 (2009).

[28] Turker H., The effect of ultraviolet radiation of pancreatic exocrine cells in mole rats: An ultrastructural study, J. Radiat. Res. Appl. Sci. 8, 49-54 (2015).

[29] Turker H., Yel M., Effects of ultraviolet radiation on mole rats kidney: A histopathologic and ultrastructural study, J. Radiat. Res. Appl. Sci. 7, 182-187 (2014).

[30] Petersen A.B., Gniadecki R., Vicanova J., Thorn T., Wulf H.C., Hydrogen peroxide is responsible for UVA-induced DNA damage measured by alkaline comet assay in $\mathrm{HaCaT}$ keratinocytes, J. Photochem. Photobiol. B. 59(1-3), 123-131 (2000).

[31] Douki T., Reynaud-Angelin A., Cadet J., Sage E., Bipyrimidine photoproducts rather than oxidative lesions are the main type of DNA damage involved in the genotoxic effect of solar UVA radiation, Biochem. 42, 9221-9226 (2003).

[32] Yel M., Turker H., Ultrastructural effects of ultraviolet $\mathrm{C}$ radiation on the stratum basale of mole rats epidermis, J. Radiat. Res. Appl. Sci. 7, 406-410 (2014).

[33] Denham J.W., Hauer-Jensen M., Peters L.J., Is it time for a new formalism to categorize normal tissue radiation injury? Inter J. Radiat. Oncol. Biol. Phys.50, 1105-1106 (2000).

[34] Mansoub NH., Sarvestani AH. Effects of gamma irradiation on histomorphology of different organs in rats, Ann .Biol. Res. 2(6), 580-585 (2011).

[35] Weiss J.F., Kumar K.S., Walden T.L., Neta R., Landauer M.R., Clark E.P., Advances in radioprotection through the use of combined agent regimens, Int. J. Radiat. Biol. 57(4), 709722 (1990).

[36] Durak D., Kalender S., Uzun F.G., Demir F., Kalender Y., Mercury chloride-induced oxidative stress in human erythrocytes and the effect of vitamins $\mathrm{C}$ and $\mathrm{E}$ in vitro, African. J. Biotechnology. 9 (4), 488-495 (2010).

[37] Verma R.S., Mehta A., Srivastava N., In vivo chlorpyrifos induced oxidative stress: attenuation by antioxidant vitamins, Pestic. Biochem. Phys. 88, 191-196 (2007).

[38] Eroglu S., Pandır D., Uzun G.F., Bas H., Protective role of vitamins $\mathrm{C}$ and $\mathrm{E}$ in diclorvos-induced oxidative stress in human erythrocytes in vitro, Biological. Research. 46(1),33-382013.

Citation: Dilek Pandir. Toxicity Effect of Ultraviolet (UV) Radiations on the Human Germ Cell and the Protective Role of Vitamin E. ARC Journal of Nutrition and Growth. 2017; 3(1): 13-18. doi: dx.doi.org/10.20431/2455-2550.0301003.

Copyright: (1) 2017 Authors. This is an open-access article distributed under the terms of the Creative Commons Attribution License, which permits unrestricted use, distribution, and reproduction in any medium, provided the original author and source are credited. 